\title{
EFFICIENCY OF CERTAIN INSECTICIDES AGAINST NYMPHS OF Bemisia tabaci (GENNADIUS) INFESTING CUCUMBER CULTIVARS UNDER DIFFERENT CLIMATIC CONDITIONS
}

\author{
Badiaa B.M. Abdel-Aziz ${ }^{2}$; Dahroug ${ }^{1}$, S.A.; Abdallah', Y.E.Y. \\ and Samir' ${ }^{2}$, M.M.S. \\ 1- Plant Protection Dept., Faculty of Agriculture, Ain Shams Univ., Cairo, Egypt \\ 2- Central Laboratory for Agricultural Climate (CLAC), Agriculture Research Center (ARC), \\ Giza, Egypt
}

Keywords: Insecticides; Thiamethoxam; Dinotefuran; Bemisia tabaci; Cucumber Cultivars; Climatic change

\section{ABSTRACT}

Two experiments were carried out at the Central Laboratory for Agricultural Climate (CLAC), Agricultural Research Center and the Experimental Research Station attached to the Faculty of Agriculture, Ain shams Univ., Shalakan, Qalyubyia Governorate. The experiments were conducted for two summer seasons in 2015 and 2016 under unheated multi span plastic house and under open field conditions. Both experiments aimed at investigating the effect of certain weather conditions on the impact of three insecticides used for the control of the cotton whitefly, Bemisia tabaci (Gennadius) nymphs on four cucumber cultivars. The aims of the plastic house experiment and open field experiment were to investigate the impact of certain climatic conditions (Temperature $\left(\mathrm{C}^{\circ}\right)$, Relative humidity (\%) on different insecticides efficiencies used for whitefly control compared to untreated check (without any insecticide application).

Lex (Dinotefuran) insecticide was the more effect on the nymphs of B.tabaci inside the plastic house or in the open field followed by Oshin (Thiamethoxam) insecticide. However Bernastar was the lowest efficiency. Concerning effect of climatic conditions, air temperature and relative humidity affected the performance of the three tested insecticides especially during the days with temperature over $35^{\circ} \mathrm{C}$.

\section{INTRODUCTION}

The populations of the pests are also affected by climate change which allowed to acquired migration of this population which may die to decrease of the agricultural productivity. Progressively founded the increase of the rainfall and temperature die to rising of the cost of some pesticides in some crops opposite the anther crops (Chen and McCarl, 2001).

One of the most specific factors affecting the process of agricultural production are the climatic factors which is considered as the determinant factor of the level of human welfare. So, the impact of climate change on the agricultural process is the most important thread that ran many organizations and this was the incentive for a lot of research in this field. The global warming has changed standards related to the climate, such as temperature, humidity and rainfall. Agriculture is one of the most important field that have affected by the climate change process (Aydinalp and Cresser, 2008).

In general Global climate change is already having major effects on ecosystems. It has become significantly one of the drivers of the process of adaptation in the present world, over and above it is predicted to occurring more climate change, (Mawdsley et al 2009)

In the recent years most climate scientists about $(52 \%)$ agree on that occurred change in the temperatures most of them gathered that the main reason for the occurrence of climate change and the rise in temperatures is human activities (Doran and Zimmerman, 2009). 


\section{MATERIAL AND METHODS}

\section{Plastic house experiment}

Cucumber (Cucums sativus L.), Parakoda and Hesham $F_{1}$ hybrid cultivars were used. Seeds were sown on the first week of March of 2015 and 2016 in foam trays contain peat moss mixed with vermiculite $(1: 1 \mathrm{v} / \mathrm{v})$ and transplanted after about two weeks. The final plant spacing was $50 \mathrm{~cm}$ in the row, $60 \mathrm{~cm}$ between rows, and $70 \mathrm{~cm}$ in between the double rows (beds).

\section{Open field experiment}

KUC and Wafer $F_{1}$ cucumber cultivars were used. Seeds were directly sown in the soil at the end of March 2015 and 2016. The final plant spacing was $50 \mathrm{~cm}$ in the row, $60 \mathrm{~cm}$ between rows. The treatments were arranged in a complete randomized block design with three replicates.

\section{The insecticides}

The insecticides used against $B$. tabaci nymphs were:

\section{i. Common name: Dinotefuran:}

Trade name Oshin (SG 20\%)

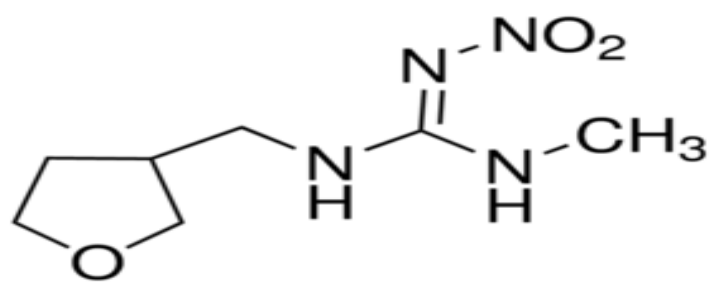

ii. Common name: Thiamethoxam:

Trade name: Lex (SG 25\%)<smiles>CN1COCN(Cc2cnc(Cl)s2)/C1=N/[N+](=O)[O-]</smiles>

\section{iii. BernaStar}

A bio-pesticide which is classified as plant extract from botanical materials as follows:

Fruits of the coconut $(40 \% \mathrm{~W} / \mathrm{W})$.

Seeds of avocado fruits (38\% W/W).

Sulfur compounds of plant origin ( $8 \% \mathrm{~W} / \mathrm{W})$.

Helping substances, water (14\% W / W)

\section{Cucumber cultivars}

i. Hybrid KUC 102

ii. Beta alpha $f 1$

iii. Waffir $\mathrm{f} 1$

\section{Method of applications}

Aerial applications are made under meteorological conditions that minimize the potential for spray drift. Although the product label does not specify droplet size, it specifically notes that small droplets (i.e., from $<150$ to 200 microns) will favor drift.

\section{Experimental design and statistical analysis}

The treatments were arranged by using a complete randomized block design with three replicates. Statistical analysis was determined by computer, using SAS program. The differences among means for all traits were tested for significance at $5 \%$ level according to the procedure described by Snedecor and Cochran (1980).

\section{Whitefly records}

Counts of $B$. tabaci nymphs were recorded on 10 cucumber leaves/replicate (a total of 30 leaves/treatment) under plastic house and open field before and after different insecticides applications.

\section{Reduction percentages}

Percentage of reduction in nymph population before and after pesticides spraying was calculated according to Henderson and Tilton (1955) formula as follow: 

under different climatic conditions

\section{Measurements of Air temperature and rela- tive humidity}

Air temperature and relative humidity were daily recorded inside the plastic house and under open field conditions by a thermometer and a hygrometer in the middle of the plastic house also the microclimate data of open field by using the agrometerogical station in both locations (CLAC and Shalakan).

\section{RESULTS AND DISCUSSION}

\section{Climatic data}

\section{i. Air temperature}

Data illustrated in Figs. (1 \& 2) show maximum and minimum air temperature inside and outside the plastic house at Dokki site and Shalakan site during seasons 2015 and 2016. Both maximum and minimum air temperature were higher inside the plastic house compared to outside at Shalakan site.

\section{ii. Relative humidity}

Data illustrated in Figs. (3 \& 4) show averages of relative humidity $(\mathrm{RH} \%)$ recorded inside the plastic house at Dokki site compared to the open field at Shalakan, Qalyubyia Governorate site.

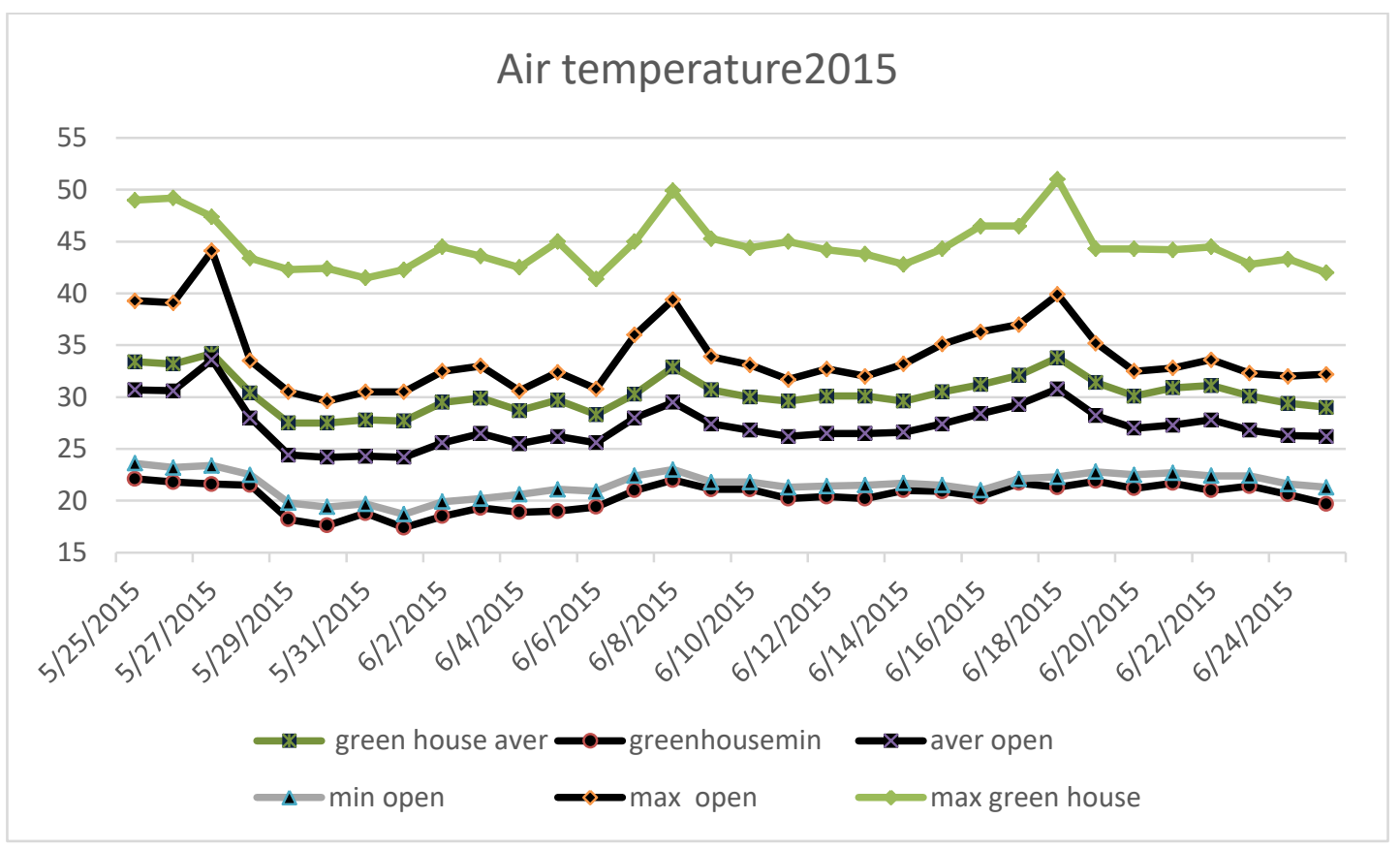

Fig. 1. Maximum and minimum air temperatures (in Celsius) inside and outside the plastic house at Dokki site and Shalakan site during the end of May until the end of June, 2015). 


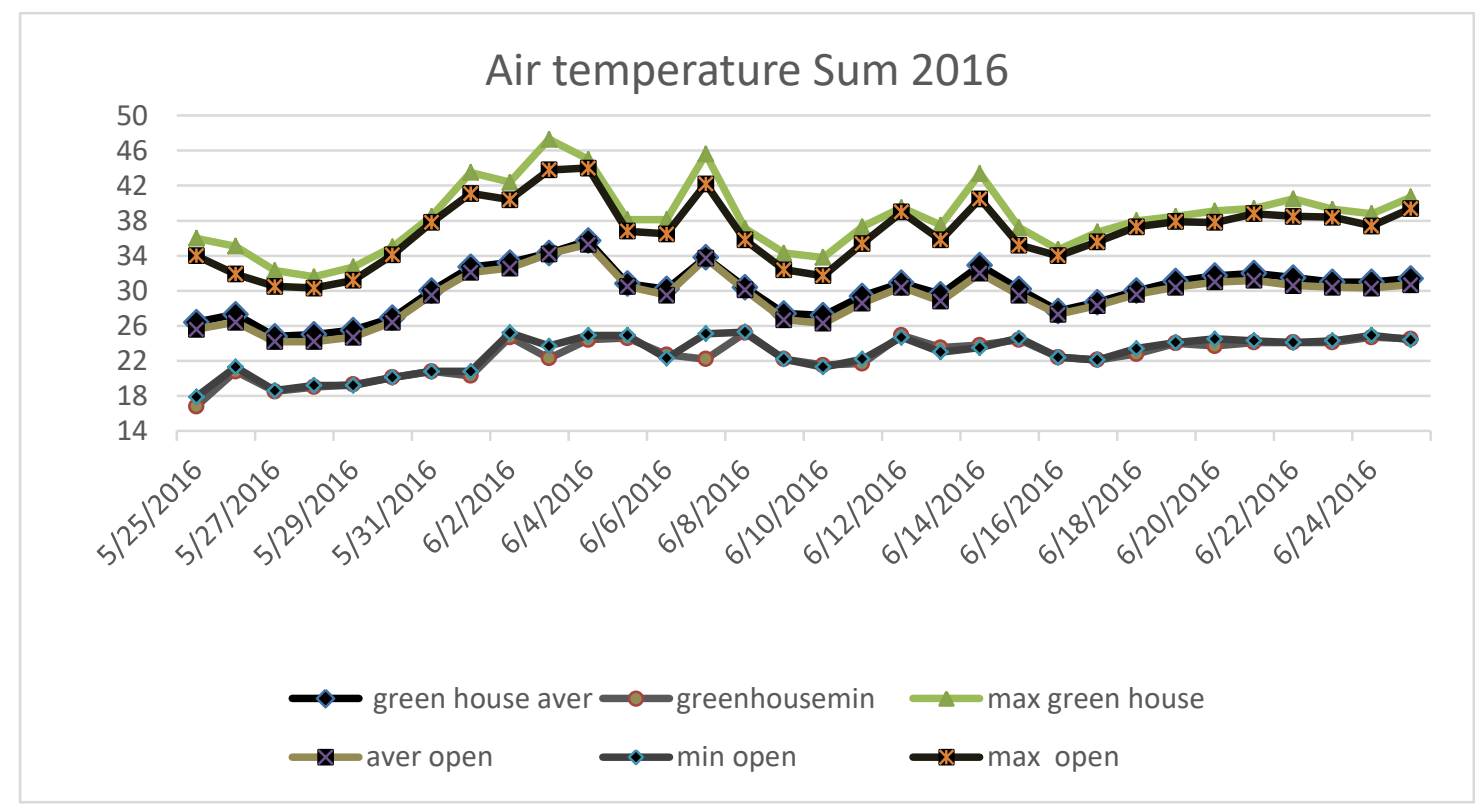

Fig. 2. Maximum and minimum air temperature (in Celsius) inside and outside the plastic house at Dokki site and Shalakan site during the end of May until the end of June, 2016.

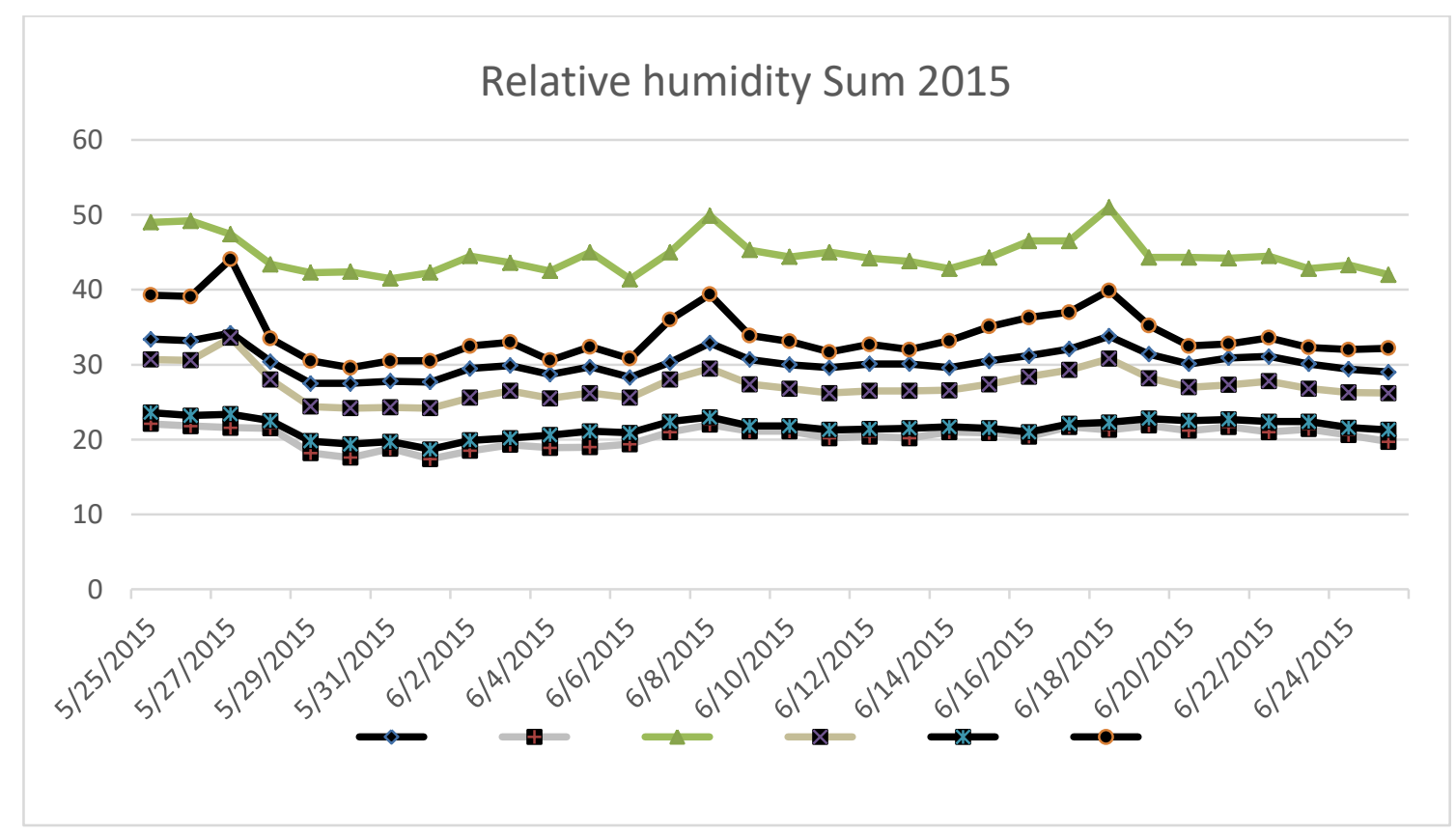

Fig. 3. Maximum and minimum relative humidity inside and outside the plastic house at Dokki site and Shalakan site during the end of May until the end of June, 2015. 


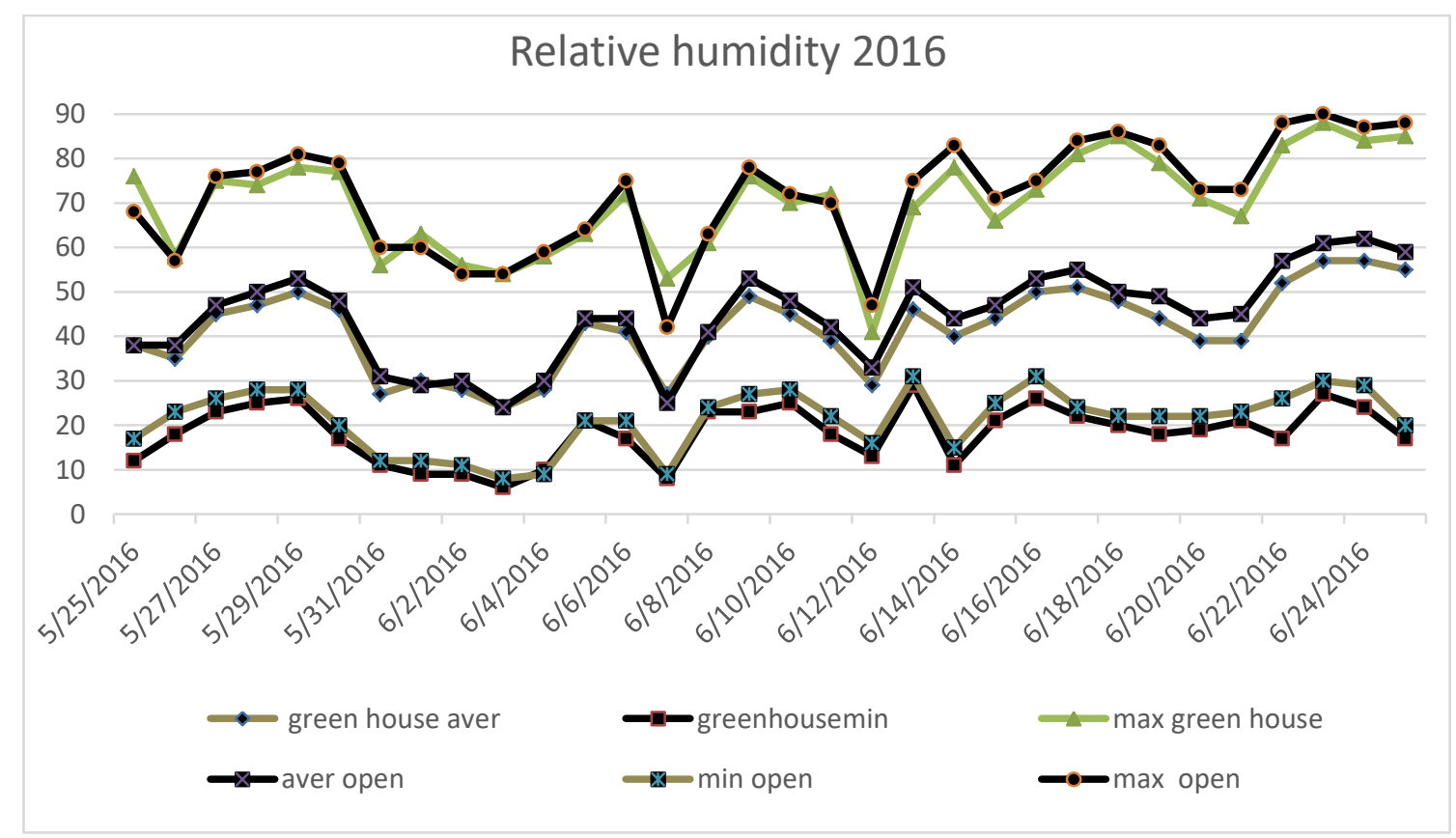

Fig. 4. Maximum and minimum relative humidity inside and outside the plastic house at Dokki site and Shalakan site during the end of May until the end of June, 2016.

\section{Reduction Percentage}

Concerning reduction percentage in $B$. tabaci nymphs population inhabiting cucumber plants (KUC cultivar) transplanted during the second week of March 2015 at Shalakan, Qalyubyia Governorate, Data in Table (1) showed that the best reduction percentage was obtained with the Lex insecticide (69.25\%) followed by Oshin (65.12\%) according to control. However, Bernastar was the lowest in reduction of $B$. tabaci nymph counts (45.39\%) according to control . (Gindin et al 2000) reported that third instar of $B$. argentifolii nymphs were used for all screening bioassay procedures when relative humidity was close to $100 \%$, the result pointed that the numbers of dead nymphs were recorded daily. However, reduction percentages in Bemisia tabaci nymph populations inhabiting with Beta-alfa cultivar (Table 2) and Barkoda cultivar (Table 4) also, pointed out that Lex is the best one followed by Oshin and Bernastar was the least but in different rate. Concerning the reduction percentages in $B$. tabaci nymph population inhabiting with Hesham cultivar at Giza Governorate (Table 3) was the only result obtained with the pesticide Oshin was the best one (59.19\%) followed by Lex $(48.03 \%)$ and the Bernastar was the lowest one (32.45). These results were observed again 2016 (Tables 5, 6, 7, 8). 
Table 1. Reduction percentage in Bemisia tabaci nymphs population inhabiting with cucumber plants (KUC cultivar) transplanted during the second week of March 2015, Shalakan, Qalyubyia Governorate:

\begin{tabular}{|c|c|c|c|c|c|c|c|c|c|c|c|}
\hline \multirow{3}{*}{ 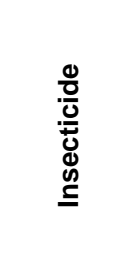 } & \multicolumn{10}{|c|}{$\%$ Reduction in B. tabaci } & \multirow{3}{*}{$\begin{array}{l}\text { General } \\
\text { Average }\end{array}$} \\
\hline & \multicolumn{5}{|c|}{ Days after first spray } & \multicolumn{5}{|c|}{ Days after second spray } & \\
\hline & 1 & 3 & 7 & 10 & Average & 1 & 3 & 7 & 10 & Average & \\
\hline Oshin & 83.68 & 75.92 & 76.43 & 64.09 & 74.32 & 62.25 & 52.81 & 51.37 & 49.52 & 55.92 & 65.12 \\
\hline Lex & 97.11 & 95.32 & 94.78 & 95.74 & 95.69 & 56.25 & 56.07 & 35.40 & 18.72 & 42.80 & 69.25 \\
\hline Bernastar & 70.70 & 25.28 & 65.75 & 6.86 & 61.22 & 19.33 & 18.54 & 33.66 & 29.16 & 29.56 & 45.39 \\
\hline
\end{tabular}

Table 2. Reduction percentage in Bemisia tabaci nymphs population inhabiting cucumber plants (Beta-alfa cultivar) transplanted during the second week of March 2015, Shalakan, Qalyubyia Governorate.

\begin{tabular}{|c|c|c|c|c|c|c|c|c|c|c|c|}
\hline \multirow{3}{*}{ 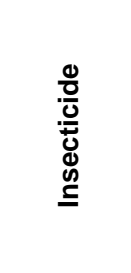 } & \multicolumn{10}{|c|}{ \% Reduction in B. tabaci } & \multirow{3}{*}{$\begin{array}{l}\text { General } \\
\text { Average }\end{array}$} \\
\hline & \multicolumn{5}{|c|}{ Days after first spray } & \multicolumn{5}{|c|}{ Days after second spray } & \\
\hline & 1 & 3 & 7 & 10 & Average & 1 & 3 & 7 & 10 & Average & \\
\hline Oshin & 72.43 & 63.76 & 57.13 & 50.42 & 60.79 & 58.94 & 56.76 & 53.85 & 51.28 & 54.59 & 59.19 \\
\hline Lex & 81.67 & 72.85 & 70.13 & 71.21 & 74.10 & 28.18 & 8.66 & 33.18 & 17.75 & 21.96 & 48.03 \\
\hline Bernastar & 60.17 & 50.21 & 31.49 & 45.79 & 47.26 & 22.38 & 15.53 & 32.43 & 3.23 & 17.63 & 32.45 \\
\hline
\end{tabular}



under different climatic conditions

Table 3. Reduction percentage in Bemisia tabaci nymphs population inhabiting cucumber plants (Hesham cultivar) transplanted during the second week of March 2015, Dokki, Giza Governorate

\begin{tabular}{|c|c|c|c|c|c|c|c|c|c|c|c|}
\hline \multirow{3}{*}{ 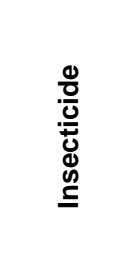 } & \multicolumn{10}{|c|}{ \% Reduction in B. tabaci } & \multirow{3}{*}{$\begin{array}{l}\text { General } \\
\text { Average }\end{array}$} \\
\hline & \multicolumn{5}{|c|}{ Days after first spray } & \multicolumn{5}{|c|}{ Days after second spray } & \\
\hline & 1 & 3 & 7 & 10 & Average & 1 & 3 & 7 & 10 & Average & \\
\hline Oshin & 89.37 & 89.22 & 86.28 & 74.78 & 83.62 & 31.24 & 15.96 & 10.42 & 8.99 & 16.6 & 50.12 \\
\hline Lex & 87.31 & 80.91 & 72.45 & 62.97 & 73.62 & 77.52 & 66.57 & 36.72 & 19.29 & 50.44 & 62.03 \\
\hline Bernastar & 26.25 & 56.32 & 51.91 & 59.74 & 52.21 & 23.32 & 9.08 & 3.34 & 5.42 & 10.50 & 31.35 \\
\hline
\end{tabular}

Table 4. Reduction percentage in Bemisia tabaci nymphs population inhabiting cucumber plants (Barkoda cultivar) transplanted during the second week of March 2015, Dokki, Giza Governorate.

\begin{tabular}{|c|c|c|c|c|c|c|c|c|c|c|c|}
\hline \multirow{3}{*}{\begin{tabular}{l}
$\stackrel{0}{0}$ \\
\hdashline 0 \\
$\underline{0}$ \\
$\mathbb{d}$ \\
$\underline{\mathscr{O}}$
\end{tabular}} & \multicolumn{10}{|c|}{ \% Reduction in B. tabaci } & \multirow{3}{*}{$\begin{array}{l}\text { General } \\
\text { Average }\end{array}$} \\
\hline & \multicolumn{5}{|c|}{ Days after first spray } & \multicolumn{5}{|c|}{ Days after second spray } & \\
\hline & 1 & 3 & 7 & 10 & Average & 1 & 3 & 7 & 10 & Average & \\
\hline Oshin & 83.34 & 72.07 & 69.43 & 55.21 & 69.18 & 61.88 & 57.94 & 54.17 & 34.42 & 52.34 & 60.76 \\
\hline Lex & 96.85 & 95.01 & 93.98 & 95.09 & 95.21 & 79.59 & 75.34 & 40.26 & 11.92 & 52.12 & 73.66 \\
\hline Bernastar & 70.03 & 40.17 & 59.79 & 58.05 & 57.24 & 21.99 & 28.57 & 17.53 & 3.29 & 18.32 & 37.78 \\
\hline
\end{tabular}


Table 5. Reduction percentage in Bemisia tabaci nymphs population inhabiting cucumber plants (KUC cultivar) transplanted during the second week of March 2016, Shalakan, Qalyubyia Governorate

\begin{tabular}{|c|c|c|c|c|c|c|c|c|c|c|c|}
\hline \multirow{3}{*}{ 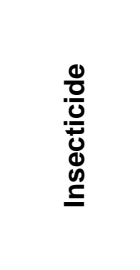 } & \multicolumn{10}{|c|}{$\%$ Reduction in B. tabaci } & \multirow{3}{*}{$\begin{array}{l}\text { General } \\
\text { Average }\end{array}$} \\
\hline & \multicolumn{5}{|c|}{ Days after first spray } & \multicolumn{5}{|c|}{ Days after second spray } & \\
\hline & 1 & 3 & 7 & 10 & Average & 1 & 3 & 7 & 10 & Average & \\
\hline Oshin & 89.37 & 74.80 & 70.59 & 62.13 & 74.20 & 34.53 & 57.62 & 36.60 & 44.77 & 45.90 & 60.05 \\
\hline Lex & 89.89 & 82.03 & 79.35 & 83.83 & 83.98 & 39.78 & 48.60 & 29.16 & 27.62 & 37.07 & 60.525 \\
\hline Bernastar & 63.18 & 69.80 & 63.90 & 56.05 & 40.07 & 17.87 & 42.45 & 10.88 & 7.41 & 24.77 & 32.42 \\
\hline
\end{tabular}

Table 6. Reduction percentage in Bemisia tabaci nymphs population inhabiting cucumber plants (Beta-alfa cultivar) transplanted during the second week of March 2016, Shalakan, Qalyubyia Governorate

\begin{tabular}{|c|c|c|c|c|c|c|c|c|c|c|c|}
\hline \multirow{3}{*}{ 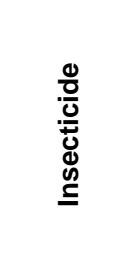 } & \multicolumn{10}{|c|}{ \% Reduction in B. tabaci } & \multirow{3}{*}{$\begin{array}{l}\text { General } \\
\text { Average }\end{array}$} \\
\hline & \multicolumn{5}{|c|}{ Days after first spray } & \multicolumn{5}{|c|}{ Days after second spray } & \\
\hline & 1 & 3 & 7 & 10 & Average & 1 & 3 & 7 & 10 & Average & \\
\hline Oshin & 91.95 & 89.82 & 87.85 & 82.26 & 87.00 & 20.38 & 12.41 & 5.03 & 5.61 & 10.41 & 46.335 \\
\hline Lex & 90.76 & 83.61 & 76.52 & 71.91 & 78.62 & 80.35 & 62.15 & 37.70 & 49.25 & 46.82 & 62.72 \\
\hline Bernastar & 46.11 & 61.81 & 60.53 & 69.14 & 61.65 & 47.41 & 21.35 & 14.40 & 6.21 & 22.46 & 42.055 \\
\hline
\end{tabular}



under different climatic conditions

Table 7. Reduction percentage in Bemisia tabaci nymphs population inhabiting cucumber plants (Hesham cultivar) transplanted during the second week of March 2016, Dokki, Giza Governorate

\begin{tabular}{|c|c|c|c|c|c|c|c|c|c|c|c|}
\hline \multirow{3}{*}{ 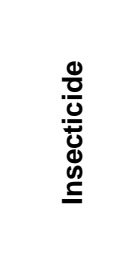 } & \multicolumn{10}{|c|}{$\%$ Reduction in B. tabaci } & \multirow{3}{*}{$\begin{array}{r}\text { General } \\
\text { Average }\end{array}$} \\
\hline & \multicolumn{5}{|c|}{ Days after first spray } & \multicolumn{5}{|c|}{ Days after second spray } & \\
\hline & 1 & 3 & 7 & 10 & Average & 1 & 3 & 7 & 10 & Average & \\
\hline Oshin & 72.51 & 66.15 & 61.00 & 49.32 & 62.16 & 62.55 & 57.40 & 59.09 & 50.92 & 57.07 & 59.62 \\
\hline Lex & 82.12 & 74.57 & 73.06 & 70.56 & 73.36 & 37.22 & 56.16 & 12.93 & 27.14 & 31.03 & 53.2 \\
\hline Bernastar & 63.50 & 54.94 & 37.33 & 44.79 & 50.32 & 21.00 & 111.12 & 24.72 & 36.46 & 33.25 & 41.79 \\
\hline
\end{tabular}

Table 8. Reduction percentage in Bemisia tabaci nymphs population inhabiting cucumber plants (Barkoda cultivar) transplanted during the second week of March 2016,Dokki, Giza Governorate

\begin{tabular}{|c|c|c|c|c|c|c|c|c|c|c|c|}
\hline \multirow{3}{*}{ 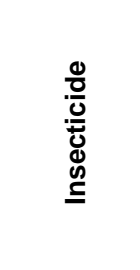 } & \multicolumn{10}{|c|}{$\%$ Reduction in B. tabaci } & \multirow{3}{*}{$\begin{array}{r}\text { General } \\
\text { Average }\end{array}$} \\
\hline & \multicolumn{5}{|c|}{ Days after first spray } & \multicolumn{5}{|c|}{ Days after second spray } & \\
\hline & 1 & 3 & 7 & 10 & Average & 1 & 3 & 7 & 10 & Average & \\
\hline Oshin & 93.11 & 89.68 & 70.94 & 70.83 & 80.23 & 46.13 & 23.41 & 19.81 & 8.83 & 24.52 & 52.375 \\
\hline Lex & 85.94 & 78.52 & 78.26 & 82.03 & 81.05 & 20.90 & 21.43 & 25.9 & 35.01 & 25.81 & 53.43 \\
\hline Bernastar & 48.25 & 63.66 & 61.59 & 50.14 & 55.73 & 16.71 & 5.91 & 7.33 & 5.46 & 8.36 & 32.045 \\
\hline
\end{tabular}

\section{Insecticide Efficiency}

Data in Table (9) showed the efficiency of different tested insecticides during summer seasons of 2015 and 2016 on count of B. tabaci nymph on cucumber plants transplanted during the second week of March. Lex insecticides recorded significantly the lowest nymph count on cucumber plants, followed by Oshin, However Bernastar was the highest significantly insecticide counts during the first spray. This result was true after 1, 3, 7 and 10 days after spraying. Moreover the same result was found also after the second spray. The same trend of results was confirmed during the second 
season (2016) showed in Table (10). Torres et al (2003) reported that the lowest thiamethoxam dose, $0.5 \mathrm{mg}$ per plant, did not affect nymph survival 15, 30 and 45 days after application on either type of cotton plant. The $1.0 \mathrm{mg}$ per plant dose reduced survival of nymphs at 15 and 30 days after application, although the effects on nectarines plants were less pronounced than on nectaried plants. However, the highest thiamethoxam concentration affected nymphal survival up to day 30 after application on nectariless cotton plants, and up to day 45 on nectaried cotton plants. The effect of thiamethoxam doses on nymph developmental time was greater at 15 days and 30 days posttreatment than at 45 days in nectaried cotton, and at 15 days than at 30 days and 45 days in nectariless cotton plants. However, this effect was reduced as the thiamethoxam doses decreased to 1.0 and $0.5 \mathrm{mg}$ per plant and with increasing time after application. On days 30 and 45 after insecticide application, developmental times for nymphs reared on nectaried cotton plants continued to be affected by the insecticide dose, whereas nymphs reared on nectariless cotton plants exhibited similar nymphal periods between treated and untreated plants. Neonicotinoids which are a class of insecticides that have played a major role in pest management for two decades. The popularity of neonicotinoids has driven this class to global sales from approximately US $\$ 1.56$ billion in 2006 , representing nearly $17 \%$ of the global insecticide market, to $24 \%$ of the global insecticide market by 2008 (Pandey et al 2009).

Table 9. Statistical analysis for the counts of $B$. tabaci nymphs during cucumber plant stransplanted during the second week of March 2015

\begin{tabular}{|c|c|c|c|c|c|c|c|c|}
\hline \multirow{3}{*}{ 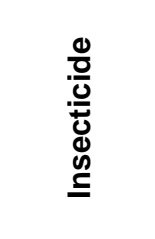 } & \multicolumn{8}{|c|}{$\%$ Reduction in B. tabaci } \\
\hline & \multicolumn{4}{|c|}{ Days after first spray } & \multicolumn{4}{|c|}{ Days after second spray } \\
\hline & 1 & 3 & 7 & 10 & 1 & 3 & 7 & 10 \\
\hline Oshin & $36.20^{c}$ & $55.00^{\mathrm{c}}$ & $66.13^{\mathrm{c}}$ & $110.00^{b}$ & $48.06^{\mathrm{c}}$ & $60.60^{\circ}$ & $71.20^{c}$ & $80.40^{\mathrm{c}}$ \\
\hline Lex & $20.47^{d}$ & $33.87^{d}$ & $43.07^{d}$ & $50.80^{\mathrm{c}}$ & $18.53^{d}$ & $26.60^{d}$ & $38.60^{d}$ & $43.73^{d}$ \\
\hline Bernastar & $79.67^{b}$ & $102.73^{b}$ & $102.20^{b}$ & $110.80^{b}$ & $88.20^{b}$ & $103.67^{\mathrm{b}}$ & $114.47^{b}$ & $135.93^{b}$ \\
\hline Control & $293.33^{\mathrm{a}}$ & $326.67^{\mathrm{a}}$ & $347.73^{\mathrm{a}}$ & $384.40^{\mathrm{a}}$ & $397.00^{\mathrm{a}}$ & $469.93^{\mathrm{a}}$ & $440.86^{\mathrm{a}}$ & $468.33^{\mathrm{a}}$ \\
\hline LSD & 3.51 & 4.51 & 5.96 & 5.00 & 5.14 & 15.02 & 12.44 & 14.24 \\
\hline SE & 1.23 & 1.58 & 2.08 & 1.75 & 1.80 & 5.26 & 4.35 & 4.98 \\
\hline
\end{tabular}



under different climatic conditions

Table 10. Statistical analysis for the counts of $B$. tabaci nymphs during cucumber plants transplanted during the second week of March 2016

\begin{tabular}{|c|c|c|c|c|c|c|c|c|}
\hline \multirow{3}{*}{ 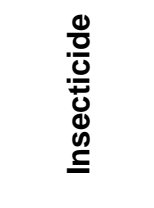 } & \multicolumn{8}{|c|}{$\%$ Reduction in B.tabaci } \\
\hline & \multicolumn{4}{|c|}{ Days after first spray } & \multicolumn{4}{|c|}{ Days after second spray } \\
\hline & 1 & 3 & 7 & 10 & 1 & 3 & 7 & 10 \\
\hline Oshin & $35.73^{c}$ & $51.53^{c}$ & $69.93^{c}$ & $112.07^{b}$ & $46.86^{c}$ & $63.0^{c}$ & $74.46^{c}$ & $84.87^{c}$ \\
\hline Lex & $20.93^{d}$ & $34.06^{d}$ & $42.60^{d}$ & $51.13^{c}$ & $17.6^{d}$ & $19.20^{d}$ & $48.47^{d}$ & $49.6^{d}$ \\
\hline Bernastar & $79.53^{b}$ & $103.13^{b}$ & $101.93^{b}$ & $111.73^{b}$ & $77.93^{b}$ & $87.6^{\mathrm{b}}$ & $127.2^{b}$ & $134.13^{b}$ \\
\hline Control & $315.73^{a}$ & $315.53^{a}$ & $354.93^{\mathrm{a}}$ & $411.07^{\mathrm{a}}$ & $418.8^{a}$ & $425.27^{\mathrm{a}}$ & $443.0^{a}$ & $417.47^{\mathrm{a}}$ \\
\hline LSD & 5.79 & 3.81 & 5.12 & 4.84 & 16.48 & 8.65 & 11.93 & 9.55 \\
\hline SE & 2.02 & 1.33 & 1.79 & 1.69 & 5.77 & 3.026 & 4.17 & 3.34 \\
\hline
\end{tabular}

\section{REFERENCE}

Aydinalp, C. and Cresser, M.S. 2008. The Effects of Global Climate Change on Agriculture. Agricultural Economics, 3(5), 672-676.

Chen, C.C. and McCarl, B.A. 2001. An investigation of the relationship between pesticide usage and climate change. Climatic Change, 50(4), 475-487.

Doran, P.T. and Zimmerman, M.K. 2009. Examining the scientific consensus on climate change. Eos, 90(3), 22-23.

Gindin, G., Geschtovt, N.U., Raccah, B. and Barash, I. 2000. Pathogenicity ofVerticillium lecanii to different developmental stages of the silverleaf whitefly, Bemisia argentifolii. Phytoparasitica, 28(3), 229-239.

Henderson, C.F. and Tilton, E.W. 1955. Tests with acaricides against the brow wheat mite, J. Econ. Entomol. 48, 157-161.
Mawdsley, J.R., O'Malley, R. and Ojima, D.S. 2009. A review of climate-change adaptation strategies for wildlife management and biodiversity conservation. Conservation Biology, 23(5), 1080-1089.

Pandey, G., Dorrian, S.J., Russell, R.J. and Oakeshott, J.G. 2009. Biotransformation of the neonicotinoid insecticides imidacloprid and thiamethoxam by Pseudomonas sp. 1G. Biochemical and Biophysical Research Communications 380, 710-714.

Snedicor, G.W. and Cochran, W.G. 1981. Statistical methods. 7th lowa State Univ. Press, lowa, USA, pp. 225-320.

Torres, J.B., Silva-Torres, C.S.A. and Barros, R. 2003. Relative effects of the insecticide thiamethoxam on the predator Podisus nigrispinus and the tobacco whitefly Bemisia tabaci in nectaried and nectariless cotton. Pest Management Science, 59(3), 315-323. 